\title{
Peran intensitas bermain game online dan pola asuh permisif orangtua terhadap tingkat agresivitas pada remaja awal di Kota Denpasar
}

\author{
I Made Dian Permana dan David Hizkia Tobing \\ Program Studi Sarjana Psikologi, Fakultas Kedokteran, Universitas Udayana \\ davidhizkia@yahoo.com
}

\begin{abstract}
Abstrak
Kebiasan bermain game online diminati tidak hanya oleh anak-anak, remaja, bahkan juga dewasa. Remaja memiliki keinginan yang tinggi untuk menghabiskan waktu bersama teman sebayanya. Keinginan ini dapat mengakibatkan remaja memiliki intensitas yang tinggi pada game online, serta memungkinkan lebih banyak terpapar konten kekerasan yang dapat memicu timbulnya agresivitas. Perilaku agresif bisa dikurangi dengan melibatkan peran keluarga dalam mendidik anak. Pendidikan berkaitan dengan pola asuh. Pola asuh yang kurang memiliki kendali dan kurangnya aspek hukuman dalam kejelasan komunikasi orangtua dengan anak disebut pola asuh permisif. Tujuan dari penelitian ini untuk mengetahui apakah intensitas bermain game online dan pola asuh permisif orangtua berperan terhadap meningkatnya agresivitas pada remaja awal di kota Denpasar. Penelitian ini menggunakan metode kuantitatif dengan pemilihan subjek menggunakan cluster sampling. Subjek berjumlah 80 orang, terdiri dari 61 laki-laki dan 19 perempuan dengan rentang 15-18 tahun yang rata-rata usia 15,85 tahun dan mayoritas berusia 16 tahun. Teknik pengujian hipotesis menggunakan uji regresi ganda. Penelitian menggunakan 3 alat ukur, yaitu Skala Intensitas Bermain Game Online berdasarkan pengertian Chaplin, Nashori, Blinka dan Smahel dengan reliabilitas 0,872, Skala Pola Asuh Permisif berdasarkan aspek Baumrind dengan reliabilitas 0,866, dan Skala Agresivitas berdasarkan bentuk agresivitas menurut Johnson dan Medinnus dengan reliabilitas 0,941. Signifikansi hasil uji regresi ganda sebesar 0,000 $(\mathrm{p}<0,05)$, berarti intensitas bermain game online dan pola asuh permisif berperan terhadap agresivitas. Koefisien regresi sebesar 0,566 berarti intensitas bermain game online dan pola asuh permisif cukup berperan terhadap tingkat agresivitas. Koefisien determinasi sebesar 0,320 berarti intensitas bermain game online dan pola asuh permisif menentukan $32 \%$ taraf agresivitas.
\end{abstract}

Kata kunci: Agresivitas, game online, intensitas bermain game online, pola asuh permisif.

\begin{abstract}
It is not only kids or teenagers but also adults like playing online games. Adolescents always want to spend most of their time with their friends. It leads them to have a high intensity to play online games as well as be exposed by violent content which lead aggressiveness. Aggressive behavior can be minimized by involving the role of family in educating children. Education is related to parenting. Parenting which has lack of control and punishment is called permissive parenting. The current study aims to find out whether the intensity of playing online games and permissive parenting have a role in the increase of aggressiveness of adolescent in Denpasar. Quantitative method and cluster sampling were applied. There were 80 subjects that consisted of 61 men and 19 women around 15-18 years old with average age was 15.85 years old and the majority was 16 years old. Multiple regression analysis was applied as the hypothesis testing technique. The study used three measuring instruments, there were intensity scale of playing online games based on the definition of Chaplin, Nashori, Blinka and Smahel with reliability of 0.872 , permissive parenting scale based on Baumrind's aspect with reliability of 0.866 , and aggressiveness scale based on the form of aggressiveness according to Johnson and Medinnus with reliability of 0.941 . The significance of multiple regression test results of $0.000(p<0.05)$ which means the intensity of playing online games and permissive parenting contribute to aggressiveness. The regression coefficient of 0,566 means the intensity of playing online games and the permissive parenting have sufficient contribution to the level of aggressiveness. The coefficient of determination of 0.320 means the intensity of playing online game and permissive parenting determines $32 \%$ of the level of aggressiveness.
\end{abstract}

Keywords: Aggressiveness, online games, intensity of playing online games, permissive parenting. 


\section{LATAR BELAKANG}

Game online menjadi tren yang banyak diminati tidak hanya oleh kalangan anak-anak, remaja, bahkan juga dewasa. Game online banyak diminati dikarenakan pemain tidak lagi bermain sendirian, tetapi dapat bermain dengan banyak orang sekaligus dari berbagai tempat yang berbeda diseluruh penjuru dunia. Pesatnya perkembangan teknologi internet diikuti juga oleh peningkatan game online yang terlihat dari munculnya berbagai jenis permainan online seperti GTA $V$ (Grand Theft Auto V), DotA 2 (Defense of the Ancients), CS:GO (Counter Strike:Global Offensive), Point Blank dan masih banyak lagi game online lainnya (Haqq, 2016).

Survey yang dilakukan oleh APJII (Asosiasi Penyelenggara Jasa Internet Indonesia) pada tahun 2014 menunjukkan bahwa terdapat 88,1 juta penduduk Indonesia menggunakan internet, dengan 10,1 persen kegiatan yang dilakukan adalah bermain game online dan video call. Survey APJII pada tahun 2016 menunjukkan bahwa terjadi peningkatan pengguna internet menjadi 132,7 juta orang dari yang sebelumnya pada 2014 sebanyak 88,1 juta. Peningkatan ini tentu saja akan mengakibatkan peningkatan pada jumlah orang yang penggunaan internetnya bertujuan untuk bermain game online dan video call (APJII, 2016).

Berdasarkan studi pendahuluan yang telah peneliti lakukan juga didapati bahwa disatu sisi game online bisa menjadi sarana pelepas penat dalam rutinitas sehari-hari, namun disisi lain ketika game online ini dimainkan dalam intensitas yang tinggi maka bisa berpengaruh pada psikologis pemain. Beberapa warnet yang telah dikunjungi didaerah Denpasar menunjukkan bahwa pada remaja yang yang berkunjung ke warnet dengan tujuan bermain game online sebagian besar sudah mengalami fase kecanduan untuk bermain game online. Fase ini merupakan fase ketika pemain game online sering menampilkan beberapa model perilaku agresif (Permana, 2017).

Perilaku agresif akibat dari permainan game online ini sebenarnya bisa dikurangi dengan melibatkan peran keluarga didalamnya. Pembinaan dan pendidikan terhadap individu tergambar dalam pola asuh orangtua. Perilaku agresif ini dipengaruhi juga salah satunya oleh pola asuh orangtua, ketika seorang remaja yang tumbuh dalam lingkungan yang penuh dengan ancaman dan kekerasan dalam hal ini kekerasan dari konten pada game online yang dimainkan sehingga akan membentuk remaja untuk belajar bertengkar dan berkelahi (Diponegoro \& Malik, 2013).

Remaja awal adalah transisi dari masa kanak-kanak menuju masa dewasa. Remaja awal mulai berpikir secara egosentris, memandang diri unik dan tidak terkalahkan. Perubahan dalam sosio-emosional pada remaja awal meliputi tuntutan mencapai kemandirian, adanya konflik dengan orangtua, serta keinginan untuk menghabiskan waktu bersama teman sebayanya. Respon yang dapat diberikan orangtua terhadap perubahan-perubahan tersebut adalah dengan memberikan tanggung jawab yang lebih besar pada remaja untuk membuat keputusan (Santrock, 2007).

Keinginan untuk menghabiskan waktu dengan teman sebaya pada remaja yang bermain game online banyak dihabiskan dengan bermain game online bersama teman-temannya, baik teman pada dunia nyata maupun teman di dunia maya. Keinginan tersebut mengakibatkan remaja tersebut memiliki intensitas yang tinggi pada game online dan memungkinkan lebih banyak terpapar konten-konten kekerasan pada game yang dimainkan. Tanggung jawab dalam mengambil keputusan yang dibebankan kepada remaja sering kali membuat remaja lupa pada hal-hal mendasar seperti mandi, makan dan belajar dikarenakan perhatian yang penuh terhadap permainan game online (Putik, 2014).

Peran orangtua sangat dibutuhkan dalam pengawasan anak ketika bermain game online. Pemantauan anak ketika bermain ini juga termasuk dalam kaitannya dengan pola asuh. Orangtua yang cenderung memanjakan anak-anaknya memiliki peranan yang cukup besar jika dikaitkan dengan intensitas bermain game online dan pengaruhnya terhadap agresivitas. Orangtua yang mendidik anak-anaknya dengan cara memanjakan dan memenuhi segala keinginan anaknya memiliki dampak negatif terhadap perkembangan anak. Pola asuh yang kurang memiliki kendali dan kurangnya aspek hukuman dalam kejelasan komunikasi orangtua dengan anak disebut pola asuh permisif (Sanjiwani, 2014).

Berdasarkan permasalahan yang telah dipaparkan, perlu diketahui apakah terdapat peran intensitas bermain game online dan pola asuh permisif orangtua terhadap tingkat agresivitas pada remaja awal di kota Denpasar serta apakah intensitas bermain game online dan pola asuh permisif secara terpisah berperan terhadap tingkat agresivitas remaja awal di kota Denpasar. Penelitian ini diharapkan mampu memberikan manfaat secara teoretis terhadap ilmu psikologi perkembangan dan juga ilmu psikologi sosial. Penelitian ini diharapkan dapat memberikan manfaat praktis bagi orangtua untuk dapat memahami peran penting pola asuh dalam terbentuknya agresivitas pada remaja. Selain itu juga bermanfaat bagi orangtua, untuk dapat mengetahui dampak intensitas bermain game online terhadap agresivitas. Bagi remaja, dapat menambah pengetahuan terkait peran intensitas bermain game online terhadap agresivitas yang timbul, sehingga remaja lebih bijak lagi dalam memilih permainan dan terhindar dari dampak negatif game online. Bagi guru atau tenaga pendidik bermanfaat untuk menambah pengetahuan terkait agresivitas yang muncul pada remaja, sehingga mampu memberikan pendidikan perilaku kepada para remaja.

\section{METODE PENELITIAN}

\section{Variabel dan Definisi Operasional}

Variabel bebas dalam penelitian ini adalah intensitas bermain game online dan pola asuh permisif. Variabel tergantung yang digunakan dalam penelitian ini adalah tingkat agresivitas. Definisi operasional dari masing-masing variabel dalam penelitian ini adalah sebagai berikut:

Intensitas Bermain Game Online

Intensitas bermain game online diukur menggunakan skala Intensitas Bermain Game Online (IBGO) berdasarkan definisi menurut Chaplin (2009), Nashori (2005), serta Blinka dan Smahel (dalam Young \& Abreu, 2017). Aspek-aspek dari intensitas bermain game online tersebut meliputi frekuensi serta lama waktu. Semakin tinggi skor yang diperoleh dari subjek, maka semakin tinggi pula taraf intensitas bermain 
game online subjek, begitu juga sebaliknya semakin rendah skor yang diperoleh subjek, maka semakin rendah pula taraf intensitas bermain game online subjek.

Pola Asuh Permisif

Pola asuh permisif diukur menggunakan skala Pola Asuh Permisif (PAP) yang menggunakan dimensi yang dijelaskan oleh Baumrind (dalam Lestari, 2012) meliputi kontrol/tuntutan (demandingness) dan penerimaan/ketanggapan (responsiveness). Semakin tinggi skor yang diperoleh dari subjek, maka semakin tinggi pula taraf penerapan pola asuh permisif orangtua terhadap subjek, begitu juga sebaliknya semakin rendah skor yang diperoleh subjek, maka semakin rendah pula taraf penerapan pola asuh permisif orangtua terhadap subjek.

Agresivitas

Tingkat agresivitas akan diukur menggunakan skala Agresivitas (Ag) yang menggunakan dimensi yang berasal dari bentuk-bentuk agresivitas yang dijelaskan oleh Johnson dan Medinus (1976) yakni perilaku fisik, menyerang suatu objek, perilaku verbal, serta melanggar hak milik/melanggar hak orang lain. Semakin tinggi skor yang diperoleh dari subjek, maka semakin tinggi pula kecenderungan perilaku agresif yang dimiliki subjek, begitu juga sebaliknya semakin rendah skor yang diperoleh subjek, maka semakin rendah pula kecenderungan perilaku agresif yang dimiliki subjek.

\section{Responden}

Populasi dalam penelitian ini adalah remaja awal yang ada di kota Denpasar yang bermain game online. Subjek dalam penelitian ini memiliki karakteristik sebagai berikut:

1. Subjek merupakan remaja awal yang berusia 12 sampai 18 tahun

2. Subjek merupakan remaja awal yang tinggal di kota Denpasar

3. Subjek minimal sudah bermain game online sejak 2 bulan terakhir

4. Subjek merupakan pemain game online dengan menggunakan media komputer atau laptop

5. Subjek merupakan pemain game online yang memainkan game online yang mengandung unsur kekerasan (jenis MMORPG, action, adventure, shooter game, RTS).

Teknik pengambilan sampel yang digunakan dalam penelitian ini adalah cluster sampling. Cluster Sampling biasanya digunakan untuk menentukan subjek dari sumber data yang sangat luas. Pada proses pengambilan data, kuesioner yang disebarkan berjumlah 100 buah, dengan 80 kuesioner bisa digunakan sebagai data penelitian, sedangkan 20 kuesioner gugur dikarenakan tidak memenuhi salah satu poin karakteristik subjek penelitian yaitu tinggal di kota Denpasar.

\section{Tempat Penelitian}

Penelitian dilakukan pada bulan April 2018. Pengambilan data penelitian dilakukan melalui proses random untuk memilih sampel daerah. Sampel daerah yang digunakan adalah Denpasar Utara dan Denpasar Barat. Subjek penelitian ini adalah remaja awal yang berusia 12 sampai dengan 18 tahun yang berdomisili di daerah Denpasar Utara dan Denpasar Barat.

\section{Alat Ukur}

Alat ukur yang digunakan pada penelitian ini menggunakan tiga skala. Skala pertama adalah skala intensitas bermain game online, yang disusun berdasarkan definisi menurut Chaplin (2009), Nashori (2005), serta Blinka dan Smahel (dalam Young \& Abreu, 2017). Skala kedua yaitu skala pola asuh permisif, yang disusun berdasarkan dimensi yang dijelaskan Baumrind (dalam Lestari, 2012). Skala terakhir adalah skala agresivitas yang disusun berdasarkan dimensi yang berasal dari bentuk-bentuk agresivitas yang dijelaskan oleh Johnson dan Medinus (1976).

Skala intensitas bermain game online terdiri dari 12 aitem pernyataan, kemudian skala pola asuh permisif terdiri dari 21 aitem pernyataan, dan terkahir skala agresivitas terdiri dari 47 aitem pernyataan. Pernyataan dalam penelitian ini terdiri dari aitem-aitem favorable dan unfavorable. Skala yang digunakan dalam penelitian ini terdiri dari empat alternative jawaban, yaitu sangat setuju (SS), setuju (S), tidak setuju (TS), dan sangat tidak setuju (STS).

Alat ukur yang valid dan reliabel adalah syarat untuk mampu memberikan informasi dan hasil data yang akurat (Azwar, 2015). Pengukuran validitas isi dilakukan dengan jalan professional judgment serta penyesuaian aitem-aitem alat ukur dengan indikator perilaku yang akan diukur (Azwar, 2012). Validitas konstruk dilakukan dengan melihat koefisien korelasi aitem total sama atau lebih besar dari 0,30 dianggap sudah cukup. Aitem mungkin saja gugur dalam tes, sehingga apabila jumlah aitem yang lolos tidak mencukupi bisa dipertimbangkan menurunkan batas kriteria menjadi 0,25 (Azwar, 2015). Uji reliabilitas dalam penelitian ini menggunakan Cronchbach Alpha dan alat ukur dikatakan reliabel apabila memberikan nilai koefesien Croncbach Alpha minimal 0,60 (Ghozali, 2005).

Hasil uji validitas skala intensitas bermain game online memiliki rentangan koefisien korelasi aitem total antara 0,310 sampai 0,724. Uji reliabilitas dilakukan pada skala intensitas bermain game online dengan menggunakan Alpha Cronbach menunjukkan hasil nilai koefisien Alpha $(\alpha)$ sebesar 0,872 . Nilai koefisien Alpha $(\alpha)$ sebesar 0,872 memiliki arti bahwa skala intensitas bermain game online mampu mencerminkan $87,2 \%$ variasi skor murni subjek. Hasil uji validitas skala pola asuh permisif memiliki rentangan koefisien korelasi aitem total antara 0,341 sampai 0,657. Uji reliabilitas dilakukan pada skala pola asuh permisif dengan menggunakan Alpha Cronbach menunjukkan hasil nilai koefisien Alpha $(\alpha)$ sebesar 0,866. Nilai koefisien Alpha $(\alpha)$ sebesar 0,866 memiliki arti bahwa skala pola asuh permisif mampu mencerminkan $86,6 \%$ variasi skor murni subjek. Hasil uji validitas pada skala agresivitas memiliki rentangan koefisien korelasi aitem total antara 0,296 sampai 0,723. Uji reliabilitas dilakukan pada skala agresivitas dengan menggunakan Alpha Cronbach yang menunjukkan hasil nilai koefisien Alpha $(\alpha)$ sebesar 0,941 . Nilai koefisien Alpha $(\alpha)$ sebesar 0,941 memiliki arti bahwa skala agresivitas mampu mencerminkan 94,1\% variasi skor murni subjek.

\section{Teknik Analisis Data}


Sebelum melakukan analisis data penelitian, dilakukan uji asumsi terlebih dahulu berupa uji normalitas, uji linearitas, uji multikolinearitas dan uji heteroskedastisitas. Uji normalitas penelitian dilakukan dengan uji Kolmogorov-Smirnov. Uji linearitas data penelitian dilakukan dengan menggunakan analisis compare mean. Uji multikolinearitas dilakukan dengan melihat nilai dari Variance Inflation Factor (VIF) dan nilai Tolerance dan terakhir uji heteroskedastisitas dilakukan dengan uji Glejser. Pengujian hipotesis penelitian dilakukan setelah semua uji asumsi terpenuhi. Uji hipotesis pada penelitian ini menggunakan uji regresi ganda untuk menguji hipotesis mayor dan minor. Analisis data penelitian ini dilakukan dengan bantuan perangkat lunak SPSS 21.0 release for Windows.

\section{HASIL PENELITIAN}

\section{Karakteristik Subjek}

Subjek dalam penelitian ini berjumlah 80 orang, terdiri dari 61 orang laki-laki dan 19 orang perempuan. Rentang usia subjek dalam penelitian ini adalah 15-18 tahun dengan mayoritas subjek berusia 16 tahun. Mayoritas pendidikan ayah dan ibu subjek penelitian ini adalah SMA dengan persentase 57,50\% dan 55\%. Mayoritas ayah subjek bekerja sebagai pegawai swasta dengan persentase $37,50 \%$ dan ibu subjek mayoritas adalah ibu rumah tangga dengan persentase $40 \%$.

\section{Deskripsi Data Penelitian}

Hasil deskripsi data penelitian yaitu intensitas bermain game online, pola asuh permisif, dan agresivitas dapat dilihat pada tabel 1 (terlampir). Hasil deskripsi pada tabel 1 menunjukkan mean empiris lebih rendah dari mean teoritis variabel intensitas bermain game online yang menggambarkan subjek memiliki intensitas bermain game online yang cenderung rendah. Tabel 1 menunjukkan mean empiris dari variabel pola asuh permisif lebih rendah dari mean teoritisnya yang menggambarkan subjek memiliki pola asuh permisif yang cenderung renndah. Hasil deskripsi pada tabel 1 juga menunjukkan mean empiris variabel agresivitas lebih rendah dari mean teoritisnya yang menggambarkan bahwa subjek memiliki tingkat agresivitas yang cenderung rendah.

\section{Uji Asumsi}

Berdasarkan hasil uji normalitas, pada tabel 2 (terlampir) menunjukkan bahwa data pada variabel intensitas bermain game online berdistribusi normal dengan nilai KolmogorovSmirnov sebesar 1,082 dengan signifikansi 0,192 yang memiliki nilai lebih besar dari 0,05 . Tabel 2 juga menunjukkan bahwa data pada variabel pola asuh permisif berdistribusi normal dengan nilai Kolmogorov-Smirnov sebesar 1,168 dengan signifikansi 0,130 yang memiliki nilai lebih besar dari 0,05. Tabel 2 menunjukkan juga bahwa data pada variabel agresivitas berdistribusi normal dengan nilai Kolmogorov-Smirnov sebesar 1,290 dengan signifikansi 0,072 yang memiliki nilai lebih besar dari 0,05 .

Hasil uji linearitas pada tabel 3 (terlampir), menunjukkan bahwa terdapat hubungan yang linear antara variabel agresivitas dan variabel intensitas bermain game online dengan signifikansi linearity sebesar 0,002 yang lebih kecil dari 0,05 dan signifikansi deviation from linearity sebesar 0,092 yang lebih besar dari 0,05. Begitu juga hubungan antara agresivitas dan pola asuh permisif linear dengan signifikansi linearity sebesar 0,000 yang lebih kecil dari 0,05 dan signifikansi deviation from linearity sebesar 0,105 yang lebih besar dari 0,05. Dapat disimpulkan berdasarkan data tersebut bahwa terdapat hubungan linear antara agresivitas dengan intensitas bermain game online serta agresivitas dengan pola asuh permisif.

Hasil uji multikolinearitas yang ditunjukkan pada tabel 4 (terlampir) menunjukkan bahwa variabel intensitas bermain game online dan pola asuh permisif memiliki nilai tolerance sebesar 0,991 dan nilai VIF sebesar 1,009, sehingga dapat disimpulkan bahwa tidak terjadi multikolinearitas.

Berdasarkan hasil uji heteroskedastisitas pada tabel 5 (terlampir) menunjukkan bahwa kedua variabel penelitian yaitu intensitas bermain game online dan pola asuh permisif tidak terjadi heterokedastisitas. Hal ini ditunjukkan berdasarkan pada intensitas bermain game online memiliki nilai signifikansi 0,464 yang bernilai lebih besar dari 0,05, serta pada variabel pola asuh permisif juga menunjukkan nilai signifikansi lebih besar dari 0,05 yaitu sebesar 0,513 .

\section{Uji Hipotesis}

Hasil uji regresi berganda variabel intensitas bermain game online, pola asuh permisif, dan agresivitas adalah sebagai berikut (tabel terlampir)

Uji hipotesis penelitian ini menggunakan teknik regresi berganda. Hasil uji regresi berganda pada tabel 6 (terlampir) menunjukkan koefisien regresi $\mathrm{R}$ sebesar 0,566 dan koefisien determinasi ( $\mathrm{R}$ Square) sebesar 0,320. Koefisien regresi sebesar 0,566 berarti intensitas bermain game online dan pola asuh permisif cukup berperan terhadap tingkat agresivitas. Koefisien determinasi sebesar 0,320 berarti intensitas bermain game online dan pola asuh permisif menentukan $32 \%$ taraf agresivitas.

Hasil uji regresi berganda pada tabel 7 (terlampir) menunjukkan $\mathrm{F}$ hitung sebesar 18,131 dan signifikansi sebesar 0,000 yang bernilai lebih kecil dari 0,05. Dapat disimpulkan model regresi dalam penelitian ini dapat digunakan untuk memprediksi agresivitas. Kesimpulan yang didapatkan adalah bahwa intensitas bermain game online dan pola asuh permisif secara bersama-sama berperan terhadap agresivitas.

Hasil uji regresi berganda pada tabel 8 (terlampir) menunjukkan intensitas bermain game online memiliki signifikansi 0,004 yang bernilai lebih kecil dari 0,05, sehingga intensitas bermain game online berperan secara signifikan terhadap agresivitas. Pola asuh permisf memiliki signifikansi 0,000 yang bernilai lebih kecil 0,05 , sehingga pola asuh permisif berperan secara signifikan terhadap agresivitas. Nilai koefisien beta terstandarisasi pola asuh permisif lebih besar daripada nilai koefisien beta terstandarisasi intensitas bermain game online. Hal tersebut menunjukkan bahwa pola asuh permisif memiliki peran lebih banyak terhadap agresivitas 
dibandingkan dengan intensitas bermain game online terhadap agresivitas.

Hasil uji regresi berganda pada tabel 8 dapat memprediksi taraf agresivitas dari masing-masing subjek dengan melihat persamaan garis regresi sebagai berikut:

$\mathrm{Y}=-11,860+0,631 \mathrm{X}_{1}+1,976 \mathrm{X}_{2}$

Keterangan:

Y : Agresivitas

$\mathrm{X}_{1} \quad$ : Intensitas Bermain Game Online

$\mathrm{X}_{2} \quad$ : Pola Asuh Permisif

a. Konstanta sebesar $-11,860$ menyatakan bahwa jika tidak ada penambahan atau peningkatan skor pada intensitas bermain game online ataupun pola asuh permisif maka dikatakan taraf agresivitas sebesar nol (nilai konstanta -11,860).

b. Koefisien regresi $X_{1}$ sebesar 0,631 menyatakan bahwa setiap penambahan atau peningkatan satuan skor subjek pada variabel intensitas bermain game online, maka akan terjadi kenaikan taraf agresivitas sebesar 0,631.

c. Koefisien regresi $\mathrm{X}_{2}$ sebesar 1,976 menyatakan bahwa setiap penambahan atau peningkatan satuan skor subjek pada variabel pola asuh permisif, maka akan terjadi kenaikan taraf agresivitas sebesar 1,976 .

Rangkuman hasil uji hipotesis mayor dan hipotesis minor pada penelitian ini dapat dilihat pada tabel 9 (terlampir).

\section{PEMBAHASAN DAN KESIMPULAN}

Hasil penelitian yang telah dilakukan menunjukkan bahwa hipotesis mayor pada penelitian ini diterima. Hipotesis mayor tersebut menerangkan bahwa intensitas bermain game online dan pola asuh permisif orangtua berperan terhadap agresivitas remaja awal di kota Denpasar. Hipotesis tersebut diperkuat dengan hasil analisis yang telah dilakukan yang mana didapat hasil sumbangan efektif dari intensitas bermain game online dan pola asuh permisif secara bersama-sama berperan sebesar $32 \%$ terhadap agresivitas pada remaja awal. Dari hasil analisis tersebut mengindikasikan $68 \%$ sisanya adalah peran dari faktor lain terhadap agresivitas.

Berdasarkan hasil kategorisasi agresivitas subjek, diketahui bahwa mayoritas subjek memiliki tingkat agresivitas yang rendah. Subjek dengan tingkat agresivitas rendah tersebut berjumlah 47 orang dari total 80 orang, yang jika dipersentasekan adalah sebesar 58,75\%. Tingkat agresivitas pada subjek tersebut dipengaruhi oleh variabel intensitas bermain game online serta pola asuh permisif orangtua. Nilai $\mathrm{R}$ sebesar 0,566 dari hasil analisis menunjukkan bahwa terdapat peran antara variabel bebas intensitas bermain game online dan variabel bebas pola asuh permisif terhadap variabel tergantung yaitu agresivitas.

Hasil tersebut sesuai dengan pendapat dari King (2010) yang mengatakan bahwa salah satu faktor timbulnya agresivitas adalah faktor sosio-kultural yaitu tingkat orang-orang menonton kekerasan. Hal tersebut juga didukung oleh penelitian dari Bushman dan Anderson (dalam Taylor, Peplau \& Sears, 2009) yang menunjukkan bahwa memainkan video game yang mengandung unsur kekerasan dapat menimbulkan ekspektasi permusuhan terhadap orang lain yang bisa berujung pada perilaku agresi. Faktor pola asuh permisif yang menjadi salah satu faktor agresivitas juga sesuai dengan pendapat Baumrind (dalam Santrock, 2007) yang menyebutkan dampak dari pola asuh permisif bisa mengembangkan remaja menjadi agresif.

Berdasarkan hasil analisis penelitian menunjukkan variabel intensitas bermain game online memiliki nilai koefisien beta terstandarisasi sebesar 0,279 , dengan nilai t sebesar 2,957 serta taraf signifikansi sebesar 0,004 yang bernilai lebih kecil dari 0,05 , sehingga dapat dikatakan bahwa variabel intensitas bermain game online berperan dalam meningkatkan tingkat agresivitas. Semakin tinggi intensitas bermain game online yang dimiliki remaja awal, maka semakin tinggi agresivitas remaja awal tersebut. Sebaliknya, semakin rendah tingkat intensitas bermain game online remaja awal, maka semakin rendah juga tingkat agresivitas remaja awal tersebut. Hasil penelitian ini sesuai dengan hasil penelitian yang dilakukan Haqq (2016), yang menyatakan bahwa terdapat hubungan antara intensitas bermain game online dengan agresivitas remaja awal.

King (2010) mengatakan faktor yang memicu agresivitas itu salah satunya adalah pengaruh dari sosio-kultural, dalam hal ini agresivitas dipengaruhi oleh tingkat menonton adegan kekerasan dari media. Adegan kekerasan yang dilihat oleh remaja dalam hal ini adalah berasal dari adegan kekerasan yang ditunjukkan dalam permainan yang dimainkan oleh subjek. Berkowitz (2003) juga menjelaskan adanya faktor pengaruh model dalam memicu munculnya agresivitas, yang dalam hal ini modeling bisa terjadi melalui media game online. Modeling sendiri didefinisikan sebagai pengaruh yang timbul ketika seseorang melihat orang lain yang dijadikan model bertindak dengan cara tertentu dan kemudian meniru perilaku orang lain yang dijadikan model tersebut. Model yang dipilih bisa orangtua, bisa artis, bisa juga tokoh favoritnya atau dalam kaitannya dengan game online adalah karakter yang dimainkan.

Bandura (dalam King 2007) menjelaskan terdapat empat proses dalam pembelajaran melalui pengamatan (modeling) yaitu perhatian, pengendapan, reproduksi motorik, dan penguatan. Perhatian pada pemain game online sudah tentu banyak terfokus pada karakter game yang dimainkan, dan seringkali banyak menampilkan kekerasan. Pengendapan terjadi ketika pemain menyimpan adegan-adegan kekerasan yang dimunculkan karakter game kedalam ingatannya, yang pada saat diperlukan maka ingatan tentang adegan kekerasan itu dapat dimunculkan. Reproduksi motorik kemudian terjadi yakni anak menunjukkan atau menampilkan perilaku agresif, ketika perilaku agresif ini mendapatkan penguatan, maka hal itu bisa menjadi perilaku yang menetap.

Berdasarkan hasil penelitian ini diketahui bahwa sebagian besar subjek memainkan game dengan jenis shooter (tembak- 
menembak). Subjek yang memainkan jenis shooter sebanyak 45 pilihan dari 208 jumlah pilihan atau jika dipersentasekan sebesar 21,63\%. Penelitian yang dilakukan oleh Waas (2015) tentang hubungan antara kecanduan bermain game online jenis massively multiplayer online first person shooter dengan perilaku agresif pada mahasiswa universitas Kristen Satya Wacana, yang menunjukkan bahwa terdapat hubungan yang positif dan signifikan antara kecanduan bermain game online jenis MMOFPS dengan perilau agresif pada mahasiswa. MMOFPS merupakan game online yang menyuguhkan adegan tembak-menembak didalamnya sehingga menonjolkan banyak adegan kekerasan ketika dimainkan. Hasil penelitian tersebut berarti bahwa semakin tinggi kecanduan bermain game online jenis MMOFPS maka semakin tinggi pula agresivitas seseorang.

Menurut Griffits (dalam Wass, 2015) pengaruh game online dapat menyebabkan perilaku agresif, terutama pada game yang menampilkan perkelahian, kesadisan, penyiksaan, pembunuhan. Jenis permainan yang digemari serta dimainkan berulang-ulang oleh individu akan secara tidak sadar terekam sehingga menanamkan perilaku agresif di alam bawah sadarnya. Tylor, dkk (2009) menjelaskan bahwa salah satu mekanisme penting yang membentuk perilaku seseorang adalah proses imitasi. Proses imitasi dilakukan pada hampir setiap jenis perilaku, termasuk agresi. Ketika seseorang bermain game online dengan jenis shooter yang menampilkan banyak adegan tembak-menembak dan juga kekerasan, hal tersebut akan terekam dengan mudah pada memori dan alam bawah sadar dikarenakan game tersebut dimainkan berulangulang. Selain itu dikarenakan seringnya game tersebut dimainkan maka akan memudahkan individu untuk melakukan imitasi terhadap apa yang dilihatnya, sehingga perilaku agresif akan mudah terbentuk.

Mayoritas subjek pada penelitian ini memiliki intensitas bermain game online yang berada pada kategori sedang hingga rendah, dan untuk tingkat agresivitas subjek mayoritas berada pada kategori rendah hingga sedang. Dalam penelitian ini subjek dengan intensitas bermain game online sedang berjumlah 36 orang yang jika dipersentasekan sekitar $45 \%$ dan untuk kategori rendah sebanyak 27 orang yang jika dipersentasekan menjadi 33,75\%. Tingkat agresivitas subjek yang termasuk dalam kategori rendah sebanyak 47 orang yang jika dipersentasekan sebesar 58,75\% dan untuk subjek dengan kategori sedang sebanyak 28 orang atau dipersentasekan sebesar 35\%. Hasil ini membuktikan jika intensitas bermain game online yang mengandung konten kekerasan ini memiliki skor rendah, maka skor agresivitasnya juga akan rendah.

Hal ini sesuai dengan hasil penelitian yang dilakukan Haqq (2016), yang menyatakan bahwa terdapat hubungan antara intensitas bermain game online dengan agresivitas remaja awal. Intensitas bermain game online yang mayoritas sedang hingga rendah dapat diartikan bahwa paparan terhadap konten kekerasan dari game tersebut juga sedikit. Imitasi terhadap perilaku agesif yang ditunjukkan dalam game yang dimainkan juga akan menjadi rendah. Rendahnya imitasi terhadap perilaku agresif akan meminimalisir terbentuknya perilaku agresif pada subjek yang berujung pada hasil skor agresivitas yang mayoritas rendah hingga sedang pada subjek.
Berdasarkan hasil analisis penelitian menunjukkan variabel pola asuh permisif memiliki nilai koefisien beta terstandarisasi sebesar 0,466 dengan nilai $t$ sebesar 4,939 serta taraf signifikansi sebesar 0,000 yang bernilai lebih kecil dari 0,05, sehingga dapat dikatakan bahwa variabel pola asuh permisif berperan dalam meningkatkan tingkat agresivitas. Semakin tinggi pola asuh permisif orangtua yang dimiliki remaja awal, maka semakin tinggi agresivitas remaja awal tersebut. Sebaliknya, semakin rendah tingkat pola asuh permisif orangtua yang dimiliki remaja awal, maka semakin rendah juga tingkat agresivitas remaja awal tersebut. Nilai koefisien beta terstandarisasi dari penelitian ini menunjukkan bahwa intensitas bermain game online yakni 0,279 lebih kecil daripada nilai koefisien beta terstandarisasi pola asuh permisif yang memiliki nilai sebesar 0,466 . Hal tersebut menunjukkan bahwa pola asuh permisif memiliki peran lebih besar terhadap agresivitas dibandingkan dengan peran intensitas bermain game online terhadap agresivitas.

Kategorisasi pola asuh permisif orangtua subjek dalam penelitian ini mayoritas tergolong dalam kategori sedang hingga rendah. Dari 80 subjek yang diteliti sebanyak 68 subjek atau jika dipersentasekan sebesar $85 \%$ memiliki pola asuh permisif orangtua yang sedang, dan sebanyak 9 orang atau jika dipersentasekan sebesar 11,25\% memiliki pola asuh permisif orangtua yang rendah. Kategorisasi subjek berdasarkan pendidikan ayah menunjukkan bahwa mayoritas ayah dari subjek berlatar belakang pendidikan SMA yaitu sebanyak 46 orang yang jika dipersentasekan sebesar 57,50\%. Untuk pendidikan ibu dari subjek mayoritas berlatar belakang pendidikan SMA yang berjumlah 44 orang atau dengan persentase sebesar 55,00\%. Dari hasil kategorisasi juga diketahui bahwa pekerjaan dari ayah subjek penelitian ini mayoritas sebagai pegawai swasta yang berjumlah 30 orang atau dengan persentase sebesar $37,50 \%$. Untuk pekerjaan ibu dari subjek penelitian ini mayoritas sebagai ibu rumah tangga yang berjumlah 32 orang atau dengan persentase sebesar $40,00 \%$.

Hasil dari analisis pada penelitian ini sejalan dengan penelitian dari Hanif (2005) yang menerangkan bahwa pola asuh permisif dikatakan berpeluang paling tinggi untuk menimbulkan perilaku agresif. Papalia, dkk (2009) menjelaskan bahwa pola asuh permisif menghargai ekspresi diri serta pengaturan diri. Orangtua dengan gaya permisif membuat sedikit permintaan dan membiarkan anak mengatur serta memonitor aktivitasnya sendiri. Orangtua jarang memberikan hukuman kepada anak atas keputusan dan kebijakan yang dipilih. Orangtua dengan gaya pengasuhan permisif cenderung hangat, tidak mengontrol serta tidak menuntut.

Baumrind (dalam Lestari, 2012) juga memberikan pendapat bahwa pola asuh permisif merupakan gaya pengasuhan yang menentukan sedikit aturan dan tuntutan, serta anak terlalu dibebaskan mengikuti kemauannya sendiri. Pola asuh permisif biasanya dilakukan oleh orangtua yang terlalu baik, cenderung memberi banyak kebebasan pada anak dengan menerima dan memaklumi segala perilaku, tuntutan dan tindakan anak, namun kurang menuntut sikap tanggung jawab dan keteraturan perilaku anak. Orangtua yang demikian akan menyediakan dirinya sebagai sumber daya bagi pemenuhan segala 
kebutuhan anak, membiarkan anak untuk mengatur dirinya sendiri dan tidak terlalu mendorongya untuk mematuhi standar eksternal. Baumrind (dalam Santrock, 2007) menjelaskan dampak dari pola asuh permisif yakni dapat menjadi individu yang kurang perhatian, individu yang kurang disiplin, kurang hormat, kurang sensitif, agresif dan umumnya remaja menentang kemauan orangtua, nakal, memiliki kemampuan sosialisasi yang buruk, kontrol diri yang buruk, dan kurang menghargai orang lain.

Berdasarkan penjelasan Papalia dan Baumrind dapat dikatakan bahwa faktor pola asuh permisif memiliki peran dalam terbentuknya perilaku agresif pada remaja. Semakin tinggi pola asuh permisif yang diterapkan orangtua kepada anak, maka dapat digambarkan bahwa anak tersebut akan sangat bebas karena mendapat sedikit tuntutan dari orangtua serta orangtua kurang menuntut sikap tanggung jawab dan keteraturan perilaku anak. Ketika anak berperilaku agresif sebagai akibat dari adanya pengaruh model dalam hal ini imitasi yang dilakukan terhadap karakter yang dimainkan dalam game online yang mengandung unsur kekerasan didalamnya, sedangkan orangtua kurang menuntut sikap tanggung jawab dan keteraturan perilaku, maka yang timbul adalah perilaku agresif dianggap bukan sebuah masalah oleh anak.

Pola asuh orangtua erat kaitannya dengan faktor pendidikan yang dimiliki oleh orangtua. Dalam penelitian ini mayoritas subjek memiliki orangtua dengan latar belakang pendidikan SMA. Orangtua yang memiliki pendidikan tinggi lebih banyak mengikuti kegiatan-kegiatan ilmiah, seperti seminar, lokakarya, workshop yang berhubungan dengan perkembangan anak. Orangtua yang berpendidikan tinggi akan memberikan berbagai alternatif dan jawaban dalam melakukan diskusi, sehingga membuat anak lebih matang dalam berpikir terhadap keputusan yang akan diambil (Haryanti, 2014). Hal ini didukung pula dengan penelitian yang dilakukan oleh Kharmina (2011) bahwa terdapat pengaruh positif dan signifikan antara tingkat pendidikan orangtua terhadap pola asuh. Jika pendidikan orangtua semakin baik maka pola asuh orangtua juga semakin baik.

Penelitian dari Susanti (2016) menunjukkan bahwa orangtua dengan tingkat pendidikan yang tinggi dengan orangtua berpendidikan rendah berbeda dalam pola pengasuhannya. Orangtua yang berpendidikan tinggi lebih berpengetahuan luas serta informasi yang orangtua punya dapat orangtua tersebut salurkan atau aplikasikan dengan mudah dan baik. Pola asuh yang semakin baik akan membentuk anak menjadi lebih disiplin, lebih berani berpendapat, sehingga agresivitas yang mungkin dimunculkan anak akan dapat dikontrol dengan baik.

Berdasarkan penelitian yang peneliti lakukan juga diketahui bahwa mayoritas pekerjaan ayah dari subjek adalah pegawai swasta sedangkan untuk pekerjaan ibu mayoritas adalah sebagai ibu rumah tangga. Pekerjaan orangtua ada kaitannya dengan bagaimana pola asuh orangtua, bagaimana intensitas anak bermain game online, serta bagaimana agresivitas pada anak. Orangtua yang memiliki pekerjaan yang baik dengan penghasilan yang baik akan meningkatkan status sosial dan ekonomi keluarga. Kesibukan orangtua bekerja disatu sisi akan mengakibatkan adanya kontrol yang rendah dari orangtua kepada anak, sehingga seringkali menimbulkan perilaku agresif pada anak.

Status sosial ekonomi dari keluarga memberikan andil dalam timbulnya agresi, seperti yang dijelaskan oleh King (2010) bahwa terdapat faktor sosio-kultural berupa variasi budaya yang menjadi faktor agresi. Pada negara yang memiliki kesenjangan ekonomi yang besar, kejahatan ataupun agresi cukup lumrah terjadi. Seringkali orang-orang dengan status sosial ekonomi yang rendah berperilaku lebih agresif. Hal tersebut juga sejalan dengan pendapat Berkowitz (2003) yaitu orang-orang dengan status sosial ekonomi rendah cenderung memiliki konflik keluarga yang tinggi. Menurut Berkowitz konflik keluarga merupakan salah satu faktor yang memicu agresi, anak cenderung berprilaku agresi merupakan akibat dari dirinya yang menjadi korban dari penyimpangan sosial akibat kondisi keluarga yang abnormal.

Selain konflik keluarga, status ekonomi dan sosial yang rendah juga dapat menyebabkan frustrasi. Frustrasi sendiri menurut Berkowitz (2003) serta Tylor, dkk (2009) merupakan salah satu faktor yang memicu agresi. Frustrasi yang dialami individu menurut Berkowitz (2003) memengaruhi seseorang untuk melakukan serangan. Tylor, dkk (2009) juga menjelaskan bahwa frustrasi merupakan sumber kemarahan yang muncul dari adanya hambatan atau dicegahnya upaya untuk mencapai sebuah tujuan. Ketika individu berada pada status sosial dan ekonomi yang rendah sering kali individu tersebut berusaha untuk memperbaiki status tersebut, namun ketika tujuan tersebut terhambat maka timbulah rasa frustrasi yang menimbulkan amarah serta berdampak pada munculnya perilaku agresi guna meluapkan rasa frustrasi tersebut.

Berdasarkan deskripsi data penelitian sebagian besar ayah dari subjek penelitian bekerja sebagai pegawai swasta dan biasanya memiliki pendapatan yang cukup, sehingga status sosial ekonomi keluarga tidak dapat dikatakan rendah. Status ekonomi sosial subjek yang baik, dalam hal ini tentunya dapat meminimalisir timbulnya perilaku agresi yang diakibatkan oleh faktor sosio-kultural, faktor konflik keluarga, serta faktor frustrasi. Menurut penelitian Erika (2014) orangtua yang terlalu sibuk bekerja akan kurang mendapat waktu bersama anak-anaknya, jadi orangtua tidak dapat memberikan perhatian dan kasih sayang untuk anak-anaknya. Deskripsi data penelitian juga menunjukkan mayoritas ibu memiliki pekerjaan sebagai ibu rumah tangga. Hal tersebut membuat orangtua terutama ibu memiliki waktu yang maksimal untuk berinteraksi dengan anak-anaknya, selain itu orangtua mampu menunjukkan inisiatif untuk menjalin hubungan yang dekat dengan anak. Ibu yang memiliki waktu luang yang maksimal untuk berinteraksi dengan anak akan berdampak pada intensitas bermain game online yang lebih dapat dikontrol sehingga anak tidak terlalu banyak terpapar dengan adegan kekerasan dalam game, serta anak akan cenderung mengontrol perilaku agresifnya.

Setelah melakukan prosedur analisis data penelitian, karya tulis ini telah mencapai tujuan penelitian yakni mengetahui peran intensitas bermain game online dan pola asuh permisif orangtua terhadap tingkat agresivitas pada remaja awal di kota Denpasar. Selain itu, diketahui pula peran intensitas bermain game online terhadap agresivitas pada remaja awal di kota 
Denpasar, serta mengetahui peran pola asuh permisif terhadap agresivitas pada remaja awal di kota Denpasar.

Berdasarkan penelitian yang telah dilakukan, dapat ditarik kesimpulan bahwa intensitas bermain game online dan pola asuh permisif secara berasama-sama berperan terhadap tingkat agresivitas pada remaja awal di kota Denpasar. Peran dari intensitas bermain game online terhadap tingkat agresivitas remaja awal di kota Denpasar adalah positif, yang berarti semakin tinggi intensitas bermain game online dari remaja awal, maka semakin tinggi tingkat agresivitasnya. Peran dari pola asuh permisif orangtua terhadap tingkat agresivitas remaja awal di kota Denpasar adalah positif, yang berarti semakin tinggi pola asuh permisif yang diterapkan orangtua, maka semakin tinggi tingkat agresivitas pada remaja awal.

Intensitas bermain game online yang sedang pada remaja di Denpasar berarti, remaja tidak terlalu sering melakukan aktivitas bermain game online, selain itu waktu yang digunakan untuk bermain game online juga masih dalam batas wajar. Pola asuh permisif yang sedang yang diterapkan orangtua berarti orangtua menetapkan aturan yang cukup pada anaknya. Orangtua juga memberikan berbagai tuntutan kepada anak, namun tidak berlebihan. Anak dalam hal ini tidak terlalu dibebaskan dalam memenuhi keinginannya, dan orangtua tidak selalu memenuhi dan memahami kebutuhan anak. Dukungan yang diberikan kepada anak tidak secara berlebihan ditunjukkan oleh orangtua. Orangtua juga tidak selalu memberikan reward kepada anak atas hal yang telah dilakukannya, dalam hal ini orangtua memberikan reward pada perilaku yang memang pantas mendapatkan reward. Tingkat agresivitas yang rendah pada remaja di kota Denpasr berarti perilaku agresif seperti memukul maupun mendorong orang lain sangat jarang dimunculkan. Remaja juga sangat jarang menyerang objek misalnya membanting benda, memukul benda, ataupun menendang benda yang ada disekitarnya. Perilaku verbal seperti mengumpat ataupun mengejek orang lain juga sangat jarang dilakukan oleh remaja, serta perilaku melanggar hak orang lain dalam bentuk merampas ataupun meminjam sesuatu milik orang lain tanpa ijin hampir tidak pernah dilakukan.

Berdasarkan kesimpulan penelitian yang telah dipaparkan, peneliti dapat memberikan saran bagi orangtua, yaitu orangtua diharapkan tidak terlalu menerapkan pola asuh permisif yang tinggi guna mengurangi intensitas bermain game online anak sehingga anak tidak tumbuh menjadi pribadi yang agresif. Orangtua diharapkan lebih bisa mengontrol waktu ketika anak bermain game online terutama game yang mengandung konten kekerasan, guna mencegah kecanduan anak terhadap game online yang bisa memngakibatkan timbulnya perilaku agresif pada anak. Orangtua diharapkan bisa lebih banyak menghabiskan waktunya bersama anak remajanya, dikarenakan masa remaja adalah masa mencari jati diri, sehingga sangat perlu mendapatkan pengawasan terkait dengan perilaku agar sesuai dengan norma-norma yang berlaku.

Saran bagi remaja awal yang dapat peneliti berikan adalah Remaja diharapkan bisa mengurangi kegemarannya bermain game online terutama jenis game online yang mengandung banyak unsur kekerasan didalamnya, guna mencegah dampak negatif ataupun perilaku agresif yang timbul akibat seringnya melihat adegan kekeran dari game yang dimainkan. Remaja sebaiknya bisa lebih banyak memainkan permainan tradisional, karena selain sebagai sarana hiburan, banyak permainan tradisional yang bisa membantu mengembangkan kemampuan kognitif, motorik kasar, motorik halus, maupun kemampuan bersosialisasi. Saran yang dapat diberikan bagi sekolah yaitu diharapkan bisa menggunakan hasil penelitian ini untuk menambah pengetahuan terkait agresivitas pada remaja, sehingga mampu lebih banyak memberikan pendidikan terkait perilaku yang baik dan tepat sesuai dengan norma yang berlaku di masyarakat.

Saran bagi penelitian selanjutnya adalah penelitian selanjutnya diharapkan bisa menambah sampel penelitian serta jumlah subjek penelitian sehingga data yang diperoleh lebih representatif dan bervariasi. Penelitian selanjutnya diharapkan bisa menyesuaikan waktu penyebaran kuesioner, hindari pembagian kuesioner kepada subjek yang sedang bermain, karena bisa memperbesar kemungkinan bias data. Usahakan memberikan kuesioner kepada subjek yang memang benarbenar sudah selesai bermain. Penelitian selanjutnya diharapkan bisa meneliti terkait cara meminimalkan dampak negatif dari bermain game online terutama jenis game yang mengandung konten kekerasan. Penelitian selanjutnya diharapkan juga bisa menambah analisis terkait pendidikan dan pekerjaan orangtua dengan pola asuh.

\section{DAFTAR PUSTAKA}

Agustiani, H. (2009). Psikologi perkembangan: Pendekatan ekologi kaitannya dengan konsep diri dan penyesuaian diri pada remaja. Bandung: PT. Refika Aditama.

Aini, H. N. (2014). Hubungan pola asuh otoriter dengan kecanduan game online pada anak usia Sekolah Dasar. Skripsi. Universitas Islam Negeri Sunan Kalijaga Yogyakarta. Diakses dari http://digilib.uinsuka.ac.id/14915/2/09710060_bab-i_iv-atauv_daftar-pustaka.pdf.

Aji, C. Z. (2012). Berburu rupiah lewat game online. Yogyakarta: PT. Bounabooks.

Ali, M. \& Asrori, M. (2004). Psikologi remaja perkembangan peserta didik. Jakarta: Bumi Aksara.

APJII. (2016). Infografis penetrasi \& perilaku pengguna internet Indonesia survey 2016. Diakses dari https://www.apjii.or.id/survei.

Ariani, R. T., \& Sawitri, D. R. (2014). Hubungan antara persepsi terhadap pola asuh orang tua otoriter dengan agresivitas pada remaja. Empati, 3(4), 492-502. Diakses dari https://ejournal3.undip.ac.id/index.php/empati/article/ view/7611

Azwar, S. (2012). Reliabilitas dan validitas. Yogyakarta: Pustaka Belajar.

Azwar, S. (2013). Metode penelitian. Yogyakarta: Pustaka Pelajar. 
Azwar, S. (2015). Dasar-dasar psikometrika (edisi ke 2). Yogyakarta: Pustaka Pelajar.

Azwar, S. (2016). Reliabilitas dan validitas (edisi ke 4). Yogyakarta: Pustaka Belajar.

Berkowitz, L. (2003). Emotional behavior: Mengenali perilaku dan tindakan kekerasan di lingkungan sekitar kita dan cara penanggulangannya buku kesatu. Jakarta: CV. Teruna Grafica.

Bryant, F., \& Smith, B. (2001). Refining the architecture of aggression: A measurement model for Buss-Perry aggression questionnaire. Journal of Research in Personality 35(2), 138-167. Diakses dari http://psycnet.apa.org/record/2001-07092-003

Candra, P. (2016, September 23). Kecanduan game online, bocah dipenjara 3 bulan karena lakukan ini. Tribun Bali. Diakses dari http://pekanbaru.tribunnews.com/2016/09/23/kecand uan-game-online-bocah-dipenjara-3-bulan-karenalakukan-ini.

Chaplin, J. P. (2009). Kamus lengkap psikologi. Jakarta: Raja Grafindo Persada.

Cross. (2009). Parenting style. University of California, Berkeley.

Diponegoro, A. M., \& Malik, M. A. (2013). Hubungan pola asuh otoritatif, kontrol diri, ketrampilan komunikasi dengan agresivitas siswa. PSIKOPEDAGOGIA Jurnal Bimbingan dan Konseling, 2(2), 101-115. Diakses dari http://journal.uad.ac.id/index.php/PSIKOPEDAGOG IA/article/view $/ 2578$

Erika, U. D. (2014). Faktor-faktor yang mempengaruhi pola asuh orang tua pada waria di Kembang Kuning Surabaya. Ejournal, 3(1). Diakses dari http://ejournal.stikeswilliambooth.ac.id/index.php/ind ex/index

Febrian, J., \& Andayani, F. (2002). Kamus komputer dan istilah teknologi informasi. Bandung: $\mathrm{CV}$ Informatika.

Geen, R. (2001). Human aggression (2nd ed). Buckingham: Open University Press.

Ghozali, I. (2005). Aplikasi analisis multivariate dengan program SPSS. Semarang: Badan Penerbit Universitas Diponegoro.

Ghozali, I. (2016). Aplikasi analisis multivariate dengan program IBMM SPSS 23. Semarang: Badan Penerbit Universitas Diponegoro.

Hanif. (2005). Perbedaan tingkat agresivitas pada siswa SMU Muhammadiyah I Yogyakarta berdasar pada pola asuh dan jenis pekerjaan orangtua. Jurnal Penelitian Humaniora, 6(2), 144-154. Diakses dari https://publikasiilmiah.ums.ac.id/handle/11617/457

Haqq, T. A. (2016). Hubungan antara intensitas bermain game online terhadap agresivitas remaja awal di warnet "A, B dan C" kecamatan Lowokwaru kota Malang. Skripsi. Universitas Islam Negeri Maulana Malik Ibrahim Malang. Diakses dari http://etheses.uinmalang.ac.id/3763/1/09410005.pdf

Hariyani, I., Marmawi, R., Sutarmanto. (2013). Hubungan pola asuh orangtua dengan perilaku agresivitas anak TK Kemala Bhayangkari 13. Jurnal Pendidikan dan
Pembelajaran, 2(4). Diakses dari http://jurnal.untan.ac.id/index.php/jpdpb/article/view/ 1934

Haryanti, D. (2014). Hubungan pola asuh orang tua dengan harga diri siswa di SMAN 1 Kretek Bantul. Skripsi. Sekolah Tinggi Ilmu Kesehatan Aisyiyah Yogyakarta. Diakses dari http://digilib.unisayogya.ac.id/285/

Hoog, M. A., \& Cooper, J. (2003). The sage handbook of social psychology. Thousand Oaks, CA: Sage Publications.

Hurlock, E. B. (1980). Psikologi perkembangan suatu pendekatan sepanjang rentang kehidupan (edisi ke 5). Jakarta: Erlangga.

Johnson, R. C., \& Medinnus, G.R. (1976). Child psychology: Behavior and development. New York: John Wiley and Son Inc.

Kharmina, N. (2011). Hubungan antara tingkat pendidikan orangtua dengan orientasi pola asuh anak usia dini. Skripsi. Universitas Negeri Semarang. Diakses dari http://lib.unnes.ac.id/6585/1/7836.pdf

King, L. A. (2010). Psikologi umum: Sebuah pandangan apresiatif buku kedua. Jakarta: Salemba Humanika.

Lestari, S. (2012). Psikologi keluarga: Penanaman nilai dan penanganan konflik dalam keluarga. Jakarta: Prenadamedia Group.

Musthafa, A. E., Ulfa, N. S., Herieningsih, S. W., \& Pradekso, T. (2015). Pengaruh intensitas bermain game online dan pengawasan orang tua terhadap perilaku agresif anak. Interaksi Online, 3(3). Diakses dari https://ejournal3.undip.ac.id/index.php/interaksionline/article/view/8867

Nashori. (2005). Hubungan antara kualitas dan intensitas dzikir dengan kelapangdadaan mahasiswa. Milab, 1(5). Diakses dari http://jurnal.uii.ac.id/Millah/article/view/5677

Papalia, D. E., Olds, S. W., \& Feldman, R. D. (2009). Human development: Perkembangan manusia (edisi ke 10). Jakarta: Salemba Humanika.

Permana, I. M. D. (2017). Studi pendahuluan: Peran intensitas bermain game online dan pola asuh permisif orangtua terhadap agresivitas pada remaja awal di kota Denpasar. (Naskah tidak dipublikasikan). Program Studi Psikologi Fakultas Kedokteran Universitas Udayana Bali.

Priyanto, D. (2012). Belajar praktis analisis parametrik dan non parametrik dengan SPSS. Yogyakarta: Gava Media.

Puspitadewi, N. W. S. (2017). Hubungan antara intensitas bermain game online dengan kecenderungan agresivitas pada komunitas gaming Surabaya. Character: Jurnal Penelitian Psikologi., 4(3). Diakses dari http://jurnalmahasiswa.unesa.ac.id/index.php/charact er/article/view/20709

Putik, N. (2014). Hubungan pola asuh otoriter dan intensitas bermain game online dengan perilaku bullying pada remaja di sekolah. Thesis. Universitas Muhammadiyah Surakarta. Diakses dari http://eprints.ums.ac.id/39305/ 
Putra, K., \& Nugroho, A. (2015). Hubungan antara pola asuh otoriter dengan agresivitas pada remaja. Skripsi. Universitas Muhammadiyah Surakarta. Diakses dari http://eprints.ums.ac.id/36742/

Rahmawan, I. A. (2013). Hubungan antara pola asuh permisif dengan intensi bullying pada siswa-siswi kelas V1ll SMP Muhammadiyah 4 Yogyakarta. EMPATHY Jurnal Fakultas Psikologi, 2(1). Diakses dari http://www.jogjapress.com/index.php/EMPATHY/art icle/view/1537

Riadi, E. (2016). Statistika penelitian (analisis manual dan IBM SPSS). Yogyakarta: ANDI Yogyakarta.

Santoso, S. (2014). Panduan lengkap SPSS versi 20. Jakarta: Elex Media Komputindo.

Santrock, J. W. (2007). Perkembangan anak jilid dua (edisi ke 7). Jakarta: Erlangga.

Sarwono, S. W. (2006). Psikologi remaja (edisi revisi). Jakarta: Rajawali Pres.

Schell, J. (2008). The art of game design: A book of lenses. Burlington: Elsevier.

Sugiyono. (2015). Metode penelitian kombinasi (mixed methods). Bandung: Alfabeta.

Susanti, E. (2016). Korelasi tingkat pendidikan orangtua dan pola asuh terhadap kemandirian anak dalam keluarga, Jurnal Pendidikan Luar Sekolah, 6(1), 13-23. Diakses dari http://journal.student.uny.ac.id/ojs/index.php/pls/artic le/view/8061

Taylor, S. E., Peplau, L. A., \& Sears, D. O. (2009). Psikologi sosial (edisi ke 12). Jakarta: Kencana Prenada Media Group.

Utomo, A. (2014). Hubungan antara intensitas bermain game online bertema kekerasan dengan perilaku agresif pada remaja di Surakarta. Skripsi. Universitas Muhammadiyah Surakarta. Diakses dari http://eprints.ums.ac.id/28986/

Waas, P. M. (2015). Hubungan antara kecanduan bermain game online jenis massively multiplayer online first person shooter dengan perilaku agresif pada mahasiswa Universitas Kristen Satya Wacana. Skripsi. Universitas Kristen Satya Wacana Salatiga. Diakses dari http://repository.uksw.edu/handle/123456789/8701

Young, K. S., \& Abreu, C. N. D. (2017). Internet addiction. Kecanduan internet, panduan konseling dan petunjuk untuk evaluasi dan penanganan. Yogyakarta: Pustaka Pelajar. 


\section{LAMPIRAN}

Tabel 1

Deskripsi Data Penelitian

\begin{tabular}{|c|c|c|c|c|c|c|c|c|}
\hline $\begin{array}{l}\text { Variabel } \\
\text { Penelitian }\end{array}$ & $\begin{array}{c}\text { Mean } \\
\text { Teoretis }\end{array}$ & $\begin{array}{c}\text { Mean } \\
\text { Empiris }\end{array}$ & $\begin{array}{l}\text { Standar } \\
\text { Deviasi } \\
\text { Teoretis }\end{array}$ & $\begin{array}{l}\text { Standar } \\
\text { Deviasi } \\
\text { Empiris }\end{array}$ & $\mathrm{X} \min \mathrm{X} \max$ & $\begin{array}{l}\text { Sebaran } \\
\text { Teoretis }\end{array}$ & $\begin{array}{l}\text { Sebaran } \\
\text { Empiris }\end{array}$ & t (sig.) \\
\hline $\begin{array}{c}\text { Intensitas } \\
\text { Bermain } \\
\text { Game } \\
\text { Online }\end{array}$ & 30 & 28,08 & 6 & 5,848 & 16 & $12-48$ & $16-48$ & $\begin{array}{l}-2,944 \\
(0,004)\end{array}$ \\
\hline $\begin{array}{c}\text { Pola Asuh } \\
\text { Permisif }\end{array}$ & 52,5 & 51,05 & 10,5 & 3,118 & 43 & $21-84$ & $43-60$ & $\begin{array}{l}-4,160 \\
(0,000)\end{array}$ \\
\hline Agresivitas & 117,5 & 106,73 & 23,5 & 13,213 & 160 & $47-188$ & $88-160$ & $\begin{array}{l}-7,294 \\
(0,000)\end{array}$ \\
\hline
\end{tabular}

Tabel 2

Uji Normalitas Data Penelitian

\begin{tabular}{lcc}
\hline \multicolumn{1}{c}{ Variabel } & Kolmogorov-Smirnov & Asymp.Sig (2-tailed) \\
& & $(\mathrm{P})$ \\
\hline Intensitas Bermain Game Online & 1,082 & 0,192 \\
Pola Asuh Permisif & 1,168 & 0,130 \\
Agresivitas & 1,290 & 0,072 \\
\hline
\end{tabular}

Tabel 3

Uji Linearitas Data Penelitian

\begin{tabular}{ccccc}
\hline & & $\mathrm{F}$ & Sig. \\
\hline $\begin{array}{c}\text { Agresivitas*Intensitas } \\
\text { Bermain Game } \\
\text { Online }\end{array}$ & $\begin{array}{c}\text { Between } \\
\text { Groups }\end{array}$ & Linearity & 10,615 & 0,002 \\
Agresivitas*Pola & $\begin{array}{c}\text { Deviation from } \\
\text { Linearity }\end{array}$ & 1,553 & 0,092 \\
Asuh Permisif & Groups & Linearity & 27,714 & 0,000 \\
& & $\begin{array}{c}\text { Deviation from } \\
\text { Linearity }\end{array}$ & 1,596 & 0,105 \\
\hline
\end{tabular}


Tabel 4

Uji Multikolinearitas Data Penelitian

\begin{tabular}{cccc}
\hline Variabel & Tolerance & $\begin{array}{c}\text { Variance Inflation } \\
\text { Factor }(\mathrm{VIF})\end{array}$ & Keterangan \\
\hline $\begin{array}{c}\text { Intensitas Bermain } \\
\text { Game Online }\end{array}$ & 0,991 & 1,009 & Tidak terjadi multikolinearitas \\
Pola Asuh Permisif & 0,991 & 1,009 & Tidak terjadi multikolinearitas \\
\hline
\end{tabular}

Tabel 5

Hasil Uji Heteroskedastisitas Data Penelitian

\begin{tabular}{ccccccc}
\hline Variabel & $\begin{array}{c}\text { Unstandardized } \\
\text { Coefficients }\end{array}$ & $\begin{array}{c}\text { Standardized } \\
\text { Coefficients }\end{array}$ & $\boldsymbol{T}$ & Sig. & Kesimpulan \\
\cline { 2 - 5 } & B & $\begin{array}{c}\text { Std. } \\
\text { Error }\end{array}$ & (Beta) & & & \\
\hline $\begin{array}{c}\text { Intensitas } \\
\text { Bermain Game } \\
\text { Online }\end{array}$ & $-0,114$ & 0,154 & $-0,084$ & $-0,736$ & 0,464 & $\begin{array}{c}\text { Tidak terjadi } \\
\text { heterokedastisitas }\end{array}$ \\
$\begin{array}{c}\text { Pola Asuh } \\
\text { Permisif }\end{array}$ & 0,190 & 0,290 & 0,075 & 0,657 & 0,513 & $\begin{array}{c}\text { Tidak terjadi } \\
\text { heterokedastisitas }\end{array}$ \\
\hline
\end{tabular}

Tabel 6

Hasil Uji Regresi Berganda Data Penelitian

\begin{tabular}{llrrr}
\hline Model & R & R Square & Adjusted $R$ Square & Std. Error of the Estimate \\
\hline 1 & $.566^{\mathrm{a}}$ & .320 & .303 & 11.035 \\
\hline
\end{tabular}

Tabel 7

Hasil uji regresi berganda signifikansi nilai $\mathrm{F}$

\begin{tabular}{llllll}
\hline & Sum of Squares & Df & $\begin{array}{l}\text { Mean } \\
\text { Square }\end{array}$ & F & Sig. \\
\hline Regression & 4415,705 & 2 & 2207,852 & 18,131 & 0,000 \\
Residual & 9376,245 & 77 & 121,769 & & \\
Total & 13791,950 & 79 & & & \\
\hline
\end{tabular}


Tabel 8

Hasil Uji Regresi Berganda Nilai Koefisien Beta Dan Nilai T Variabel Intensitas Bermain Game Online dan Pola Asuh Permisif terhadap Tingkat Agresivitas

\begin{tabular}{cccccc}
\hline & $\begin{array}{c}\text { Unstandarized } \\
\text { Coefficients } \\
\text { B }\end{array}$ & Std. Error & $\begin{array}{c}\text { Standarized } \\
\text { Coefficients } \\
\text { Beta }\end{array}$ & $\mathrm{t}$ & Sig. \\
\hline $\begin{array}{c}\text { (Constant) } \\
\text { Intensitas }\end{array}$ & $-11,860$ & 20,763 & & $-0,571$ & 0,570 \\
$\begin{array}{c}\text { Bermain Game } \\
\text { Online }\end{array}$ & 0,631 & 0,213 & 0,279 & 2,957 & 0,004 \\
$\begin{array}{c}\text { Pola Asuh } \\
\text { Permisif }\end{array}$ & 1,976 & 0,400 & 0,466 & 4,939 & 0,000 \\
\hline
\end{tabular}

Tabel 9

Rangkuman Hasil Uji Hipotesis Penelitian

\begin{tabular}{|c|c|c|}
\hline No. & Hipotesis & Hasil \\
\hline \multirow[t]{4}{*}{1.} & Hipotesis Mayor: & \\
\hline & Intensitas Bermain Game Online dan Pola Asuh & Diterima \\
\hline & Permisif Berperan terhadap Tingkat Agresivitas & \\
\hline & pada Remaja Awal di Kota Denpasar. & \\
\hline \multirow[t]{6}{*}{2.} & Hipotesis Minor: & \\
\hline & a. Terdapat Peran Antara Intensitas Bermain Game & Diterima \\
\hline & Online Terhadap Tingkat Agresivitas pada & \\
\hline & Remaja Awal di Kota Denpasar. & \\
\hline & b. Terdapat Peran Antara Pola Asuh Permisif & Diterima \\
\hline & Terhadap Tingkat Agresivitas pada Remaja Awal & \\
\hline
\end{tabular}

